\title{
Unemployment after the Great Recession: Why so High? What Can We Do?*
}

\author{
MICHAEL REICH \\ Professor of Economics and Director, Institute for Research on Labor and Employment, \\ UNIVERSITY OF CALIFORNIA, UNITED STATES. E-mail: mreich@econ.berkeley.edu
}

\begin{abstract}
The surprising increase in U.S. unemployment in the Great Recession and the persistence of long-term unemployment in the economic recovery pose important questions for employment policy. Why did unemployment grow more than forecast? Is the character of long-term unemployment the result of cyclical or structural causes? I discuss eight policy changes that would reduce the ranks of the unemployed and that would improve the efficiency of the labor market. Most of these proposals do not add big-ticket items to the Federal budget; their merits are independent of the question of how large the federal deficit should be at this time.
\end{abstract}

Keywords: Long-Term Unemployment, Unemployment Insurance, Employer Incentives.

\section{El desempleo después de la Gran Recesión: ¿Por qué tan alto? ¿Qué podemos hacer?}

\section{RESUMEN}

El sorprendente incremento en el desempleo de Estados Unidos durante la Gran Recesión y la persistencia del desempleo de larga duración plantean grandes interrogantes para la política de empleo. ¿Por qué el desempleo creció más que lo que se había predicho? ¿Es la larga duración del desempleo el resultado de causas cíclicas o estructurales? Se discuten ocho cambios de política que reducirían el volumen de desempleo y que mejorarían la eficiencia del mercado de trabajo. La mayor parte de estas propuestas no suponen un incremento del presupuesto federal de Estados Unidos. Las aportaciones de esas medidas son independientes del problema de cuán grande debería ser el déficit público federal.

Palabras clave: Desempleo de larga duración, prestación por desempleo, incentivos a las empresas.

JEL Classification: J64, J65, J68

\footnotetext{
* A shorter version of this paper was presented at the hearing "Responses to Long-Term Unemployment," Income Security and Family Support Subcommittee, Committee on Ways and Means, U. S. House of Representatives, June 10, 2010.
}

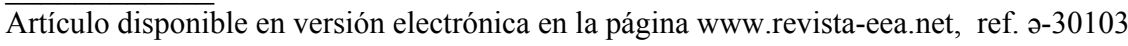




\section{INTRODUCTION}

In May 2010, a record 46 percent of the unemployed were counted by the Bureau of Labor Statistics as long-term unemployed - defined as durations of six months or more. Those who were unemployed for more than a year, whom I shall call the very-long-term unemployed, numbered 23 percent of all the unemployed. These are unprecedented figures. We know that long-term unemployment and very-long-term unemployment generate serious and long-lasting harm to millions of individuals and to the economy. The scarring effects upon the economic, mental and physical health of long-term unemployed workers and their families are well-documented (von Wachter 2010). We also know that many of the very long-term unemployed eventually leave the labor force permanently, and some of those end up on the disability rolls. Very-long-term unemployment consequently generates adverse effects upon the Treasury and upon the capacity of the economy to grow in the long-run. ${ }^{1}$

In the past two years the proportion of the unemployed who have been out of work six months or longer has grown to levels not seen since the Great Depression (Chart 1). The overall unemployment rate rose rapidly from 4.7 percent in November 2007, when the recession began, then peaked at 10.1 percent in October 2009, and it has remained just under 10 percent through May 2010. This increase was higher than had been forecast by both public and private forecasters. As has been true in previous recessions, the long-term unemployment rate grew at about the same rate as the growth in the unemployment rate (Chart 2).

In the recovery phase that began in April or May of 2009, what went up quickly has not come down very much. Since its cyclical peak of 10.1 percent in October 2009, the overall unemployment rate fell to 9.7 percent in January 2010 and remained at 9.7 percent in May 2010. But in the same period, the long-term unemployment rate has continued to skyrocket as rapidly as during the recession phase. By May 2010, the proportion of the unemployed with jobless durations of six months or more had reached 46.0 percent. $^{2}$ By comparison, in the 1957-58 recession, this proportion peaked at about 10 percent; in 1982-83, it peaked at about 26 percent.

\footnotetext{
${ }^{1}$ Chetty 2010, Rothstein 2010, Shierholz 2010, von Wachter 2010.

${ }^{2}$ The rate would be even higher if the long-term unemployed who have left the labor force or who stopped looking for several months were included.
} 


\section{Chart 1}

Of total unemployment, the share unemployed for 27 or more weeks an the unemployment rate

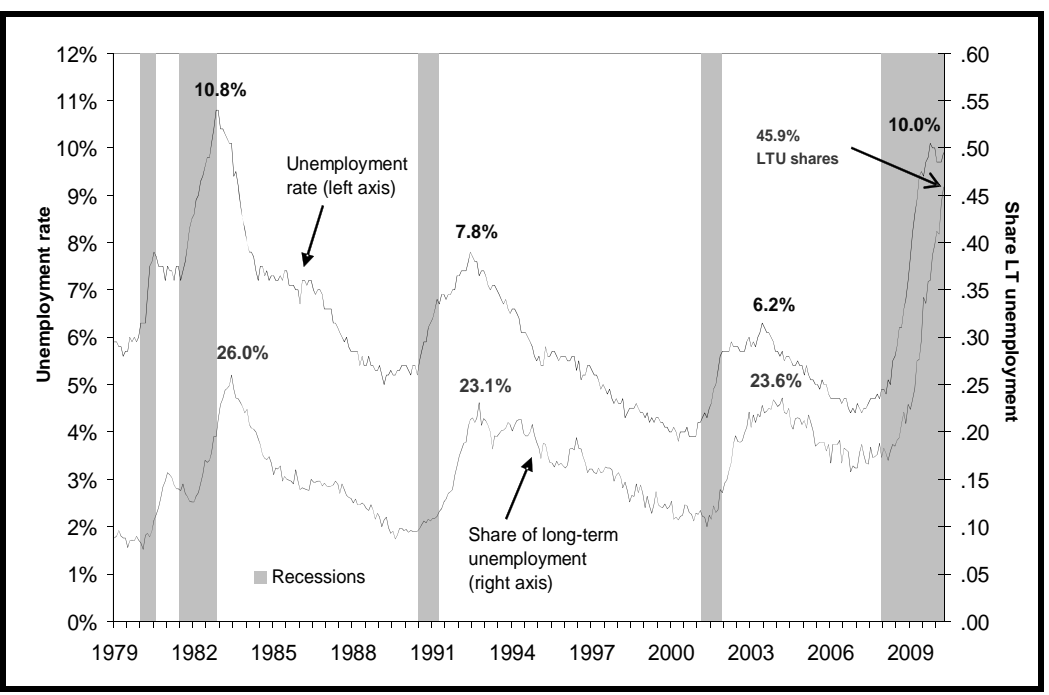

Source: Own elaboration.

\section{Chart 2}

Of total unemployment, the share unemployed for 27 or more weeks and the unemployment rate: Jan-07 to April-10

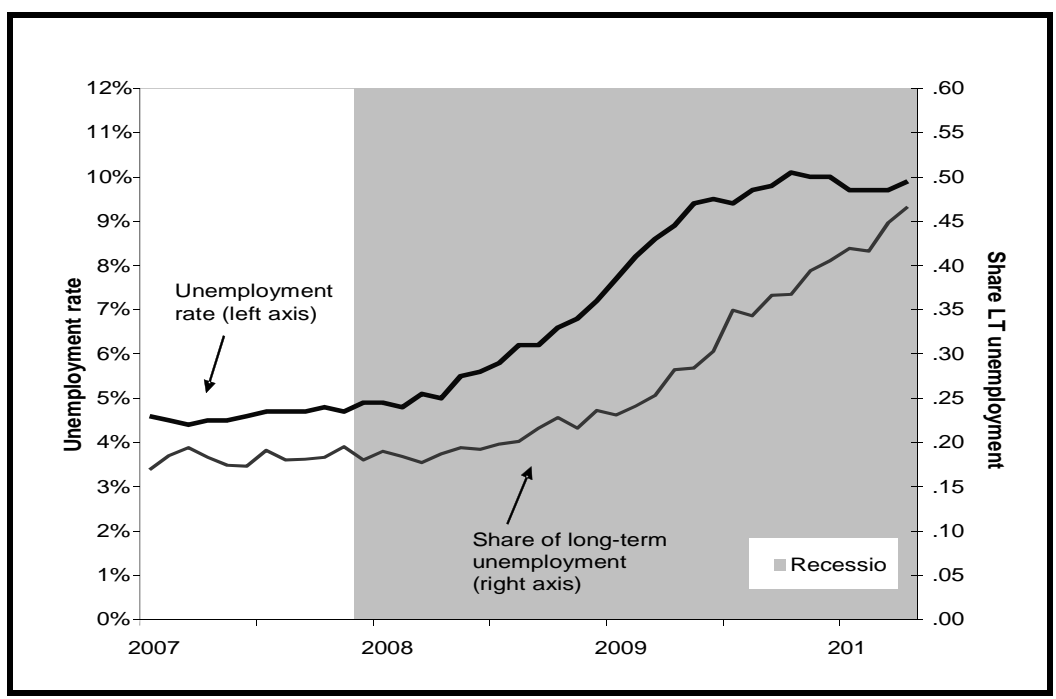

Source: Own elaboration. 
The surprising increase in unemployment and the continuing growth of longterm and very-long-term unemployment, well into the economic recovery, and in the face of repeated extensions of emergency benefits- up to 99 weeks in some states, pose important questions for employment policy. Some of these involve immediate policy issues: Have the unprecedented benefit extensions themselves kept very-long-term unemployed workers from searching for and accepting job offers? Will the economic recovery eventually reduce the number of very-long-term unemployed without further interventions? I address these questions only briefly in this paper, as excellent summaries of research on these questions are already available.

I then turn to less-studied issues concerning changes in labor market dynamics. These call for longer-term policy responses. Why did unemployment grow more than forecast? Is the character of the growing post recession longterm unemployment the result of cyclical or structural causes? I recommend eight policy changes that would reduce the ranks of the unemployed and that would improve the workings of our labor market. Most of these proposals do not add big-ticket items to the Federal budget, so their merits can be considered independently of the question of how large the federal deficit should be at this time.

\section{DO EXTENDED UNEMPLOYMENT INSURANCE BENEFITS INCREASE UNEMPLOYMENT?}

Have the unprecedented benefit extensions themselves kept very-long-term unemployed workers from searching for and accepting job offers? This is the first question most Americans ask about UI policy. According to the best credible research studies, the answer to this question is a very clear no. In previous recessions, when extensions of time limits on UI benefits were more modest, unemployed workers receiving UI benefits on average stayed out of work only one or two more weeks than those not receiving benefits. ${ }^{3}$ In the current environment, with more than five job searchers for every job opening, the evidence suggests that such effects are even smaller (Valletta and Kuang 2010).

The adverse effects of extending benefit limits beyond 99 weeks are also likely to be small. Employers generally choose to hire new labor force entrants or unemployed workers with short unemployment spells over those with longer spells. The very-long-term-unemployed are thus the least likely to receive job offers. Moreover, the remaining financial assets of this group are especially meager (Chetty 2010). Consequently, they are the least likely group among the

\footnotetext{
${ }^{3}$ Card and Levine 2000, Chetty 2010. Katz (2010) notes that consensus estimates today are much lower than in previous studies, including his own.
} 
unemployed to refuse job offers they do receive simply because they can continue to collect unemployment insurance benefits. ${ }^{4}$ The very-long-term unemployed will be the last group to benefit from an economic recovery; since unemployment rates are likely to take some time to decline, this group needs extended assistance the most. The costs of not providing assistance are far greater than the costs of having a small number of the unemployed delaying their acceptance of job offers for a couple of weeks.

\section{WILL THE ECONOMIC RECOVERY HELP THE LONG- TERM UNEMPLOYED?}

Will the economic recovery nonetheless be strong enough to eventually help the very-long-term unemployed? The Council of Economic Advisors, the Congressional Budget Office and many economists of all political stripes have forecast that the unemployment rate will decline very slowly. For example, the CEA forecasts 8.2 percent unemployment in 2012 and 6.4 in 2014, arguing that the continuing high level of unemployment is best combated by additional government-led increases in aggregate demand (CEA 2010; Romer 2010; Zandi 2010). Programs such as relief for the states and relief for teachers facing layoffs are indeed called for, and on a large scale. ${ }^{5}$ Absent such policies, unemployment will decline only very slowly. Moreover, the implementation and the benefits of these policies will occur over time. Consequently, the argument for immediately renewing emergency unemployment benefits as well as extending recipient limits beyond 99 weeks in higher unemployment states is especially compelling. So, I would add, is the case for direct job creation programs, such as those proposed in Rep. George Miller's Jobs for America Act.

Recommendation 1.- Expand radically the short-time compensation component of the UI system by federalizing this program and making it available in all 50 states. The short-time compensation program encourages employers to reduce layoffs and instead implement furloughs that are partly compensated via UI benefits. This program began in California in 1984 and is available in only 17 states today. Short-time compensation is highly popular among employers and workers who have used it. ${ }^{6}$ But it remains scandalously under utilized because

\footnotetext{
${ }^{4}$ Any extension of unemployment benefits time limits reduces the proportion of the long-term unemployed who would otherwise drop out of the labor force. This increase in the unemployment rate is generally regarded as quite small. It represents a gain to the beneficiaries and it does not indicate an unwillingness to accept job offers.

${ }^{5}$ As is well-known, such programs as well as unemployment benefits provide the highest aggregate demand multipliers (Elmendorf 2010).

${ }^{6}$ See, for example, Berkeley Policy Associates 1996 and Vroman and Brusentsev 2009.
} 
few even know of its existence and because it is needlessly bureaucratic. ${ }^{7}$ To publicize the program, UI agencies should be mandated to provide information about the program quarterly to employers of workers filing initial UI claims.

Expanding short-time compensation as a substitute for UI benefits for laidoff workers may not directly reduce costs for the UI system. But it provides economic benefits by encouraging firms and workers to maintain, to invest in, and to benefit from longer-term employment relations.

Recommendation 2.- This recommendation involves combining the shorttime compensation program with a federal tax credit. Baker (2009) estimates that a modest tax credit to businesses would reduce layoffs and generate substantial numbers of jobs, while reducing working hours modestly and leaving compensation unchanged.

\section{EXPLAINING CHANGES IN LABOR MARKET DYNAMICS}

Why did the overall unemployment rate increase so much more than private and public forecasters predicted? I argue that employers' weakening attachment to their workers, a development that began in the 1980s, has heightened the labor market's response to economic downturns. Well-working labor markets must maintain a balance between flexibility and security. But the substantial increase in labor market flexibility since the 1980s has undermined this balance, generating costs for employers and workers alike. Unfortunately, the UI system itself creates employer incentives that have reinforced the turn to greater flexibility. I suggest some reforms of the UI system that would reverse the incentives in the system and improve labor market behavior.

My discussion of the rise of long-term unemployment begins with a usual suspect: the disappearance of many jobs that may never return, in industries such as manufacturing, construction, and the finance, insurance and real estate sector. A usual argument is that unemployed workers are locked in to these industries because they do not have the skills to transfer to industries that are or will be growing. As I discuss below, my reading of the research literature suggests that the evidence for this argument is mixed. A more compelling explanation recognizes the especially long duration of the recession period and the weakness of the recovery. The reduced mobility of workers in the current crisis to areas of greater job opportunities is also important. Whatever the cause, it seems clear that many more workers are going to be joining the large group that already has been unemployed for one year or more.

\footnotetext{
${ }^{7}$ In California, employers can apply for the program only by completing forms by hand and sending them in via regular mail.
} 


\section{The growth of unemployment in the Great Recession}

Okun's Law, formulated by former CEA Chair Arthur Okun in 1962, summarizes quantitatively the responsiveness of the labor market to cyclical (detrended) changes in GDP. Based on experience in recent recessions and recoveries, Okun's Law posited that a cyclical decline of 1 percent of GDP was associated with an increase of 0.5 percent points of unemployment one year later. ${ }^{8}$ Until the current, recession, it was widely thought that Okun's Law remained a reliable guide to labor market behavior in recessions. Using this relationship, most prestigious economic forecasters expected in early 2009 that unemployment would peak at about 8 percent and fall thereafter. Okun's Law, however, did not appear to hold, as the unemployment rate peaked at above 10 percent in the second quarter of 2009. ${ }^{9}$ According to the econometric estimates of Gordon (2010), the responsiveness of unemployment to GDP changes has risen substantially since the mid1980s. Okun's Law does need revision. ${ }^{10}$

Why did layoffs and unemployment (and involuntary part-time employment) increase at a more rapid rate than Okun's Law predicted? A common answer, presented by Elsby et al. (2010), suggests that productivity growth accelerated more than had been forecast therefore leading to a lower corresponding demand for labor per increase in unit output. Elsby et al. (2010) do not however, provide an explanation for this productivity acceleration. Since productivity increases by definition when employment falls at a faster rate than output, simply pointing to productivity acceleration is to provide a tautology, not an explanation. ${ }^{11}$

Productivity growth used to be procyclical, falling during a downturn, not increasing. In eight of the nine postwar recessions through the early 1990s, productivity fell at the end of expansions and into the downturn, in part because firms held on to skilled workers even as demand for their products fell (Bauer and Shenk 2009). ${ }^{12}$ The return of productivity growth then coincided with

${ }^{8}$ In Okun's original formulation, the increase in the unemployment rate was one-third of the decrease in percent decline in GDP. The 0.5 relationship is based on the ten recessions in the period from 1947-2004. See Romer 2006, table 4.3.

${ }^{9}$ The current recession is not unique in this respect. Okun's Law also failed to predict the increases in the unemployment rate in the 1974-75 recession and the 1982-83 recession.

${ }^{10}$ Another important part of Okun's Law refers to hours per employee. The trend of involuntary part-time employment has exhibited two upward breaks, one in 2001-2 and a much larger one in the current recession. This part of Okun's Law also needs revision.

${ }^{11}$ Romer (2010) suggests that Okun's Law did hold, but that, based on GDI discrepancies with GDP, economic activity fell much more than was measured at the time. Krueger (2010) suggests that the financial crisis, marked by the collapse of Lehman Brothers, is to blame. While the financial crisis appears to have exacerbated the decline in output, Krueger's figures do not show a greater than usual decline in employment at the time of Lehman Brothers.

${ }^{12}$ Okun's Law as originally proposed also quantified this relationship: one-third of a cyclical decline in output took the form of a decline in productivity. 
economic recovery. But since the 1990 s, this pattern reversed. Productivity growth increased in the 2000-01 recession, and especially so during the Great Recession. Firms have become much quicker to lay off workers, and not only because of new technological possibilities allowing them to do more with less.

The increase in productivity growth in the recession was not the result of more rapid implementation of technological change. Among the major industrialized countries, most experienced productivity declines during the recession and only the U.S. experienced productivity increases. Rather, productivity grew because employers were shedding labor faster than they were reducing output. The consequent increases in capital per worker increased productivity. But since investment was also falling rapidly, this source of productivity growth is not sustainable. $^{13}$

Why, then, did worker shedding occur at a faster pace than in most postwar recessions? I propose that the answer involves the weakening attachments of firms to their workers. ${ }^{14}$ Since the 1980 s, employers increasingly have placed a smaller value on long-term employment relations, while also searching for ways to cut the costs of their short-term employees. This trend itself results from the extent to which managerial decisions have become driven by short-run share prices. The stock market does not valorize the firm-specific skills of long-term employees and increasingly reacts to layoff announcements as evidence of positive managerial decision-making. In other words, layoff announcements have become interpreted as a sign of increased cost-efficiency rather than one of financial stress. ${ }^{15}$ When layoffs increase share prices, managers with short-term horizons are likely to overshoot the frequency and size of layoff announcements, even if they destroy long-term assets embodied in their employees, and thereby lower the company's share prices in the longer-run (Love and Norhria 2005).

A trend toward shorter job tenure suggests why temporary layoffs have declined relative to permanent layoffs and why firms have become quicker to reduce their work forces when economic conditions become softer. The growth of sporadic or intermittent employment, a corollary of the rise of short-term

\footnotetext{
${ }^{13}$ How did firms manage to prevent large decreases in output concomitant with large layoffs? The relevant detailed data are not yet available to examine this question. The answer may involve the use of reduced work weeks, since involuntary part-time employment also grew by a surprising amount.

${ }^{14}$ Gordon (2010) examines other hypotheses also related to growing labor market flexibility.

${ }^{15}$ According to Farber and Hallock (2009), in the 1970s share prices of large companies reacted strongly and negatively to layoff announcements. This pattern began to reverse in the 1980s. By the 1990s layoff announcements were nearly as likely to generate positive effects on share prices as to generate negative ones. The changes in these responses were concentrated within manufacturing. Uchitelle (2007) suggests that the pattern turned positive in the 2000s.
} 
jobs, has placed a greater burden on the UI system, which was designed for a different era. The UI system is not working as well as it could.

\section{Evidence on the growth of sporadic and short-term jobs}

Trends in job tenure indicate how attachments between firms and their workers have evolved. Farber (2008) provides the most thorough and most upto-date study of trends in job tenure; his data cover the period from 1973 to 2006. Farber finds a substantial and steady reduction from the early 1980s to 2006 in the proportion of male private-sector workers who hold a job with the same employer for more than ten years, confirming the familiar narrative that lifetime jobs are much less common than before. ${ }^{16}$ This pattern occurred among men in all age groups and especially for men over 40.

Farber also finds that the proportion of workers who remain with the same employer for less than one year increased in the same time period. The proportion of workers in new jobs rose in all age groups, and especially among workers aged 30-39. ${ }^{17}$ In 2006 these short-term jobs accounted for one-fifth of total private sector employment. ${ }^{18}$ Equally important, in 2006 half of all new jobs ended within the first year, implying that that about a fourth of all new jobs end within six months.

Some of the decline in long-term jobs reflects the decline of industries, such as manufacturing, that had above-average job tenure levels. Similarly, some of the increase in short-term jobs reflects the rise of industries, such as retail and accommodations and food services, that long had lower levels of job tenure. As Farber reports, the shift to shorter job tenure is also visible within these industries.

\section{Excess churning in the U.S. labor market}

The growth of short-term and sporadic jobs is closely related to another key characteristic of the U.S. labor market: excess churning, which can be defined as hiring and separations above the level needed to a) accommodate cyclical changes in labor demand and supply, b) reallocate labor from declining to expanding firms, and c) absorb life-cycle related labor force entries, re-entries

\footnotetext{
${ }^{16}$ The trends for women were stable, in large part because increases in the long-term attachment of women to the labor force and to their jobs have offset occupational declines in job duration.

${ }^{17}$ Farber uses less than one year as his cutoff because information on the distribution of job tenure by months is not available for many of the years in his dataset.

${ }^{18}$ As Farber notes, over this period job duration in the public sector increased, especially but not solely among women.
} 
and exits. ${ }^{19}$ The BLS Job Openings, Layoffs, Turnover and Separation (JOLTS) data on monthly hiring and separations are often used to observe business cycle dynamics, but they are also useful to observe churning levels.

JOLTS data indicate that in November 2007 -just before the Great Recession began- private sector firms made 4.9 million new hires and experienced about the same number of separations. ${ }^{20}$ The number of hires then fell substantially, bottoming out at 3.3 million in June 2009 and then increasing to 3.9 million in April 2010. Separations (primarily quits, layoffs and discharges and retirements) remained flat at about 4.6 million through June 2009 and then fell steadily to 3.7 million in April 2010. Among separations, a rapid decline in voluntary quits offset increases in layoffs and discharges. Layoffs and discharges numbered 1.8 million in December 2007, rose sharply to a peak of 2.65 million in January of 2009, and then fell to 1.8 million by March $2010 .^{21}$

These figures tell the story of labor market adjustments over the business cycle. Hiring fell substantially in the recession, stayed flat for some time and began to turn upward only recently. Separations increased moderately in the recession and then fell substantially during the recovery, as layoffs declined.

But cyclical changes are only part of the story. Even at the depth of the Great Recession, employers made 3.3 million hires per month. Consider also the annual turnover rate, which represent the average of the hiring and separation rates over a year. Over the twelve-month period ending in March 2010, when total employment numbered nearly 139 million (as measured by the household series), employers made a remarkable 48.6 million hires. Over the 12-month period ending March 2010, the number of separations totaled 50.9 million. The turnover rate for the year ending March 2010 thus amounted to 36 percent, very close to turnover rates for much of the previous decade (Davis, Faberman and Haltiwanger 2006, Figure 4).

To some observers, such as Davis, Faberman and Haltiwanger, these turnover rates indicate a fluid labor market that is working well to reallocate jobs and workers to more productive activities. But the annual turnover rates, taken together with what we know about employee replacement costs, also suggest a highly inefficient labor market, in which each firm's annual turnover costs can be quite substantial (Dube, Freeman and Reich 2010). In my view, the labor market is too fluid; the problem is not that firms are unable to fill their job openings with workers who would make lasting matches, but rather that firms

\footnotetext{
${ }^{19}$ The term turbulence is interchangeable with churning. For an extended discussion, see Brown, Haltiwanger and Lane 2006.

${ }^{20}$ Numbers refer to seasonally adjusted data.

${ }^{21}$ In comparison, weekly initial UI claims have numbered approximately 450,000, equivalent to 1.8 million claims per month.
} 
face incentives to make shorter-term matches. The same facts seem consistent with these two very different interpretations because each interpretation takes a different view of the underlying public and private policy incentives. ${ }^{22}$ As I discuss below, although the UI system has contributed to this pattern, policy reforms could improve outcomes for both employers and workers and thereby for economic recovery and growth as well.

\section{REFORMING EMPLOYER INCENTIVES IN THE UNEMPLOYMENT INSURANCE SYSTEM}

The UI system was designed for workers who have jobs most of the time, even if they change employers frequently (as in construction and entertainment). UI does not work as well, however, for the increasing number of lowpaid workers who are employed sporadically and part-time, who move frequently from one employer to another because their jobs offer few advancement opportunities, and who often experience more than a few weeks of unemployment spells between jobs.

The incentives in the UI system have increasingly reinforced a pattern of sporadic or intermittent employment. Employers have an incentive to hire workers and to retain them for only a few quarters. They know that many workers with short-term jobs (or without documentation) will not apply for UI as it is difficult to do so when earnings are from multiple employers and sporadic, and because it may not be worth the trouble when benefits will be low. Moreover, these workers can obtain food stamps and EITC benefits (if they file income tax forms). Employers do not bear any costs for these programs as they do for UI.

The experience rating property of the UI tax is designed to counteract these effects. Experience rating penalizes employers with higher layoff rates by raising their tax rate. In practice, however, this incentive is incomplete, as it is limited by two features of the tax. In an expansionary period, many employers are already bunched at either the minimum or the maximum tax rate. When a recession is underway many more employers reach the maximum tax rate, after which the marginal tax cost to the employer is zero. Second, the maximum wage on which the tax falls has long been very low: $\$ 7,000$ to 14,000 in two-thirds of the states in 2006, similar in nominal terms but much lower in real terms to the taxable wage bases in the $1980 \mathrm{~s} .{ }^{23}$ As a result, even when it is positive, the

${ }^{22}$ Dube, Lester and Reich (2010) provide credible evidence that minimum wage increases reduce employee turnover.

${ }^{23}$ Some states have now begun to increase this ceiling substantially, especially with the incentives provided in ARRA. The ceiling should be increased in all states and indexed to wage inflation. 
marginal cost of a layoff to an employer is well below the marginal UI benefits received by the laid-off worker. ${ }^{24}$

The good news is that these incentives can be reversed. For example, empirical research (Anderson and Meyer 2000) based upon the effects of reforms made by Washington State in the 1980s, suggests that a more comprehensive experience-rated system would reduce layoffs by as much as one-third. An earlier study, by Card and Levine (1994), estimated that layoffs could be reduced by one half. Moreover, since all employers pay into a single fund that is used for all UI beneficiaries, experience rating reduces the subsidy that employers with more stable employment policies provide to employers with policies that favor less stability.

\section{Recommended policies to reverse the adverse effects of the UI system on employment durations}

Recommendation 3.- Accelerate dramatically the modernization of the UI system along the lines in ARRA. ${ }^{25}$ The current UI system for too long has made it difficult or impossible for many unemployed low-wage workers to receive UI. Expanding UI eligibility in all 50 states should be a federal priority, to be achieved perhaps by providing greater financial incentives. More rapid implementtation of these reforms should be a continuing priority.

Recommendation 4.- The experience rating system should be modernized by standardizing it among the states or transferring it to the Federal government. It should be reformed to a complete experience rating model, by adopting and going beyond the Washington State model. The marginal cost to employers should be made equal to the marginal UI benefits paid by the UI system. This will entail creating more tax brackets, increasing the rate for the highest bracket, as well as expanding the UI taxable wage base substantially and indexing it to wage inflation. Such reforms would end current inequities, in which many employers are in effect subsidizing the firms that excessively churn their workforce.

Moreover, experience rating formulas should weight more heavily employer layoffs of workers with job tenure of less than one year. This change would help to reduce the incidence of excess churning, thereby saving firms considerable turnover costs that labor market conditions impose upon them. It would also reduce taxpayers' cost of the EITC and food stamp programs.

${ }^{24}$ Card and Levine 1994 find that the marginal tax cost of layoffs to employers fell substantially from 1979 to 1986.

${ }^{25}$ Modernization includes using the most recent job quarter in the "base period" to determine benefits, raising the wage ceiling on the payroll tax, and making it easier for part-timers to receive UI benefits. 
Moving to an improved experience rating system does not require that all employers will face higher payroll taxes. A revenue-neutral reform, as proposed by Alan Krueger in the 1990s, would reduce taxes for companies that practice employment security policies while raising rates for those that do not (Uchitelle 2007: 170). Unfortunately, the Clinton Administration did not accept Krueger's proposal.

\section{THE GROWTH AND PERSISTENCE OF LONG-TERM UNEMPLOYMENT}

I turn next to the question of high and persistent long-term unemployment. It is well-known that long-term unemployment rates decline in economic recoveries, although more slowly than declines in short-term unemployment. Longterm rates lag because employers prefer to hire new labor force entrants or to hire unemployed workers with short durations. Elsby et al. (2010) confirm this relationship and suggest that it has not changed during the Great Recession. ${ }^{26}$ Romer (2010) draws the further implication that long-term unemployment today is mostly cyclical, not the result of structural changes specific to this recession, and therefore it will fall once again as aggregate demand recovers.

The trend toward longer-lasting unemployment indeed predates the current recession, as Elsby et al. suggest. Since the 1980 s, a higher proportion of layoffs have been permanent, rather than temporary. Burtless (2009) shows that the average duration of unemployment has been growing in recent recessions, as have the proportion of the unemployed who have exhausted all their unemployment insurance benefits. Kirkegaard (2009) and Allegretto and Lynch (2010) show that the successive reduction of peak unemployment rates in 1983, 1992 and 2003 were accompanied by successively smaller reductions in long-term unemployment. ${ }^{27}$ The growth and persistence of long-term unemployment thus need not be traced solely to the Great Recession.

Why then, has long-term-unemployment continued to increase? One explanation involves the unusual length of the recession --18 months and ultimately perhaps 24 months, compared to 8 to 13 months for previous recessions. This very length itself results in a large increase in the very-long-term unemployed. This group then becomes at high risk for becoming unemployable, or structurally unemployed, even if cyclical unemployment is reduced by a vigorous recovery.

${ }^{26}$ They make the important caveat that labor market adjustments since $2009 \mathrm{q} 2$ do depart from previous patterns.

${ }^{27}$ As Krueger 2008 documents, the average duration of unemployment at business cycle peaks has been rising since the 1970s. 
Another possible source of structural unemployment involves the long-term decline of some industries. This might be called the jobs that are not coming back explanation. The key issue is not just whether the jobs are coming back; it is also whether workers are locked into these industries because their skills are not transferable. Three likely candidates for such industries are the finance, insurance and real estate (FIRE) sector, construction, and manufacturing. Workers in FIRE generally are well-educated and likely to find jobs in other industries. Construction employment, which is always highly cyclical, went into free fall after the housing market collapse. But it may be stimulated by ARRA funds and by the growth of green economic standards, which affect construction more than any other sector. Manufacturing is a different story. Employment in manufacturing declined precipitously during the 2001 recession and then did not rebound in the subsequent recovery. It experienced another rapid decline during the recession. "Cash for Clunkers" and ARRA programs have had some success in helping manufacturing, although some of the ARRA support is directed to developing innovative technologies whose payoff is as yet uncertain. Considering all three industries, the prospects for growing industry-specific structural unemployment are thus mixed. ${ }^{28}$

A problem facing the locked-into-a-declining industry argument is that worker mobility across industries has been robust in recent decades. For some, the transitions have been to lower-paying jobs in industries such as building services and accommodation and food services. For others, especially those with at least some community college certification, industries such as health care will provide job opportunities that pay better. Aggregate demand policies to stimulate growth would increase these opportunities, but as already mentioned, by themselves they may not benefit the very long term unemployed for some time.

A stronger argument about the rise and persistence of long-term employment refers to the reduction of geographical labor mobility rates (Katz 2010). In the current recession, higher unemployment rates -and plausibly also higher longterm unemployment rates- are concentrated in areas that have had high foreclosure rates. Families who might want to move to areas with more job opportunities are constrained by the large asset losses they might occur if they sold their home. The benefits of mobility are also much lower in this recession. As measured by a diffusion index of unemployment among all regions, economic decline and the growth of unemployment have been more widespread than ever before, making it unclear where the unemployed should migrate for greater job opportunities. Reduced labor mobility implies that, compared to previous recessions, ${ }^{28}$ Past experience is also mixed. See Brown, Haltiwanger and Lane 2006 and Rissman 2009, who
provides a literature review and a careful examination of these issues. 
long-term unemployment will persist longer even when overall unemployment begins to fall.

Whatever the causes of very-long-term unemployment, the adverse e-ffects on future employability have been well-documented, as discussed above. We know that bouts of one year of unemployment can seriously affect not only the depreciation of skills, but also good work habits, personal self-esteem, support from family and friends, and physical health itself. In the absence of targeted programs for this group, we are likely to have large groups of workers experience unemployment for two years and considerably longer. The adverse effects are then surely going to become more serious. This consideration in itself is sufficient to justify targeted programs. I recommend the following set of policies and programs aimed at ameliorating these effects and reducing the incidence of long-term unemployment.

Recommendation 5.- UI benefits limits should be extended beyond 99 weeks- for at least 13 additional weeks in those states that continue to have double-digit unemployment rates.

Recommendation 6.- Redirect half of the ARRA/WIA training funds to the very long-term unemployed to provide stipends for attending community colleges.

Through the American Recovery and Reinvestment Act of 2009 and the Workforce Investment Act many states have received very large increases in workforce development funds. In California, for example, the Workforce Investment Boards have been allocated approximately twice the amount they received in recent years. After a long period of deliberation the California WIB has decided to allocate most of the money to the community colleges for jobrelated education, especially to train workers for green jobs.

This is admirable, both because the state's community colleges funds have been cut sharply in the state budget, and because the demand for job-related training grows in a period of rising unemployment. Moreover, the coming expansion of the health care sector will generate many middle-skill jobs, such as imaging technicians, who can be trained by community colleges. It is not clear, however, when the California construction unemployment rate is likely over 20 percent, that many green jobs will be available for many of the new community college graduates.

I suggest that the state workforce development agencies be directed to allocate some portion of these funds, perhaps half, toward education stipends for the very-long-term unemployed. This group has the least amount of resources to invest in their education, so the payoff would be greater. Stipend-recipients should be required to demonstrate that their educational plan builds upon their existing skill base in a manner that will prepare them for jobs once the labor market improves. 
Recommendation 7.- Renew and expand the subsidized jobs program in the $\$ 5$ billion TANF emergency fund.

Much of the TANF emergency money has been allocated for a 100 percent wage (but not benefit) subsidy to employers who hire the poor or unemployed. These funds are available in about 30 states, but if California's experience is typical, they are vastly underutilized. Moreover, employers who do utilize the program have a strong incentive to hire those who have been recently unemployed and who are more likely to obtain jobs anyway.

The program's funding should be renewed and expanded to all 50 states and publicity for the program should be vastly increased. The program should target hiring of those who have been unemployed the longest. This would include workers who received and are about to exhaust their UI benefits as well as those who did not receive UI benefits but can document the length of their period of unemployment.

The unprecedented high wage subsidy in this program calls for some cooperation from employers. For example, employers could be nudged to enhance the on-the-job-training they provide to their workers. Most such training in the U.S. is informal. It would have more payoff both to employers and workers if were made more structured and rewarded. ${ }^{29}$ This can be initiated by asking employers to document the amount of training they provided and the set of skills imparted.

\section{REFERENCES}

ALLEGRETTO, S. and LYNCH, D. (2010). "The changing face of the U.S. labor force and the composition of the unemployed and long-term unemployed." Unpublished paper. IRLE, UC Berkeley.

ANDERSON, P. and MEYER, B. (2000). "Effects of the Unemployment Insurance Payroll Tax on Wages, Employment, Claims, and Denials." Journal of Public Economics 78, 4: 81-106.

BAKER, D. (2009). Job-Sharing Tax Credit to Prevent Layoffs and Stimulate Employment." Issue Brief, Center for Economic Policy Research. October.

BAUER, P. and SHENK, M. (2009). "Productivity in the Recession and Going Forward." Economic Trends, Federal Reserve Bank of Cleveland.

BERKELEY POLICY ASSOCIATES et al. (1996). "An Evaluation of Short-Time Compensation. Berkeley, CA.

\footnotetext{
${ }^{29}$ For more on this issue, see Brown et al. 1997.
} 
BROWN, C.; HALTIWANGER, J. and LANE, J. (2006). Economic Turbulence: Is a Volatile Economy Good for America? Chicago: University of Chicago Press.

BROWN, C.; NAKATA, J.; REICH, M. and ULMAN, L. (1997). Work and Pay in the U.S. and Japan. New York: Cambridge University Press.

BURTLESS, G. (2009). "Unemployment Insurance for the Great Recession." Testimony to the Senate Finance Committee, September 15.

CARD, D. and LEVINE, P. (1994). "Unemployment Insurance Taxes and the Cyclical and Seasonal Properties of Unemployment." Journal of Public Economics 53, 1: 1-29.

CARD, D. and LEVINE, P. (2000). "Extended Benefits and the Duration of UI Spells: Evidence from the New Jersey Extended Benefit Program." Journal of Public Economics 78: 107-38.

COUNCIL OF ECONOMIC ADVISORS (2010). Economic Report of the President. Washington, D.C.

CHETTY, R. (2010). "Should Unemployment Benefits be Extended? An Economic Framework and Empirical Evidence." Presentation to the Economic Policy Institute, May 26.

DAVIS, S.; FABERMAN, J. and HALTIWANGER, J. (2006). "The Flow Approach to Labor Markets: New Data Sources and Micro-Macro Links." Journal of Economic Perspectives 20, 3: 3-26.

DUBE, A.; FREEMAN, E. and REICH,M. (2010). "Employee Replacement Costs." Working Paper 201-10. Institute for Research on Labor and Employment, UC Berkeley.

DUBE, A.; LESTER, W. and REICH, M. (2010). "Do Frictions Matter for Labor Markets? Minimum Wage Effects on Accessions and Separations." In progress.

ELMENDORF, D. (2010). "Policies for Increasing Economic Growth and Employment in the Short Term." Testimony to the Joint Economic Committee, February 23.

ELSBY, M.; HOBIJN, B. and SAHIN, A. (2010). "The Labor Market in the Great Recession." NBER Working Paper 15979. May.

FARBER, H. (2008). "Employment Insecurity: The Decline in Worker-Firm Attachment in the United States." Working Paper 530. Industrial Section, Princeton University.

FARBER, H. and HALLOCK, K. (2009). "The Changing Relationship Between Job Loss Announcements and Stock Prices: 1970-1999." Labour Economics 16: $1-11$.

GORDON, R. J. (2010). "Okun's Law, Productivity Innovations, and Conundrums in Business Cycle Dating." American Economic Review Papers and Proceedings 100, 2: 1-9. 
KATZ, L. (2010). "Long-Term Unemployment in the Great Recession." Testimony to the Joint Economic Committee, U.S. Congress, April 29.

KIRKEGAARD, J. (2009). "Structural and Cyclical Trends in Net Employment over U.S. Business Cycles, 1949-2009: Implications for the Next Recovery and Beyond." Working Paper 09-5, Institute for International Economics.

KRUEGER, A. (2008). "Prepared Statement" for the hearing, "Unemployment in a Volatile Economy: How to Secure Families and Build Opportunity," Health, Education and Labor and Pensions Committee, U.S. Senate. March 6.

KRUEGER, A. (2010). "Written Statement before the Joint Economic Committee." May 5.

LOVE, G. and NOHRIA, N. (2005). "Reducing Slack: the Performance Consequences of Downsizing by Large Industrial Firms, 1977-93. Strategic Management Journal 26: 1087-1108.

RISSMAN, E. (2009). "Employment Growth: Cyclical Movements or Structural Change?" Federal Reserve Bank of Chicago. Economic Perspectives 30, 4: 49-57.

ROMER, C. (2010). "Finishing the Job: The Policies Needed to Ensure Full Recovery and Fiscal Stability in the United States." OECD Forum, Paris, May 27.

ROMER, D. (2006). Advanced Macroeconomics. Third Edition. New York: McGraw-Hill.

ROTHSTEIN, J. (2010). Presentation to the forum, "Long-Term Unemployment: Causes, Consequences, and Solution." Economic Policy Institute May 26.

SHIERHOLZ, H. (2010). Presentation to the forum, "Long-Term Unemployment: Causes, Consequences, and Solution." Economic Policy Institute May 26.

UCHITELLE, L. (2007). The Disposable American: Layoffs and Their Consequences. New York: Vintage.

VALLETTA, R. and KUANG, K. (2010). "Extended Unemployment and UI Benefits." Economic Letter 2010-12, Federal Reserve Bank of San Francisco. April.

VROMAN, W. and BRUSENSTEV, V. (2009). "Short-time Compensation as a Means to Stabilize Employment." Urban Institute, November.

VON WACHTER, T. (2010). "Long-term Unemployment: Causes, Consequences and Solutions." Testimony to the Joint Economic Committee, U.S. Congress, April 29, 2010.

ZANDI, M. (2010). Testimony to the Senate Finance Committee, April 14. 